\title{
Responsabilidade fiscal: análise dos gastos com pessoal do Poder Executivo nos municípios da Região Metropolitana de Fortaleza
}

Fiscal Responsibility: Analysis of personnel expenditure on Executive branch in the cities of the Metropolitan Region of Fortaleza

\author{
Vanessa dos Santos Avelino ${ }^{1}$ \\ Marcus Vinícius Veras Machado \\ Denise Maria Moreira Chagas Corrêa ${ }^{3}$
}

\section{RESUMO}

A Lei de Responsabilidade Fiscal (LRF) possui o propósito de prevenir e corrigir desvios que afetem o equilíbrio das contas públicas, principalmente as metas de resultados entre receitas e despesas públicas. As despesas com pessoal (DP) representam valores relevantes nas contas públicas, tendo em vista que consomem uma considerável fatia do orçamento e podem comprometer os recursos destinados aos investimentos. Esta pesquisa tem como objetivo geral analisar os gastos com pessoal do Poder Executivo nos municípios da Região Metropolitana de Fortaleza (RMF), no período de 2008 a 2017. Para tanto, avaliou-se a participação das despesas com pessoal em relação à receita corrente líquida (RCL) de cada município da RMF, e verificou-se se os valores gastos com pessoal sofreram alterações em função das variações na arrecadação de receitas. Quanto à abordagem do problema, trata-se de um estudo quantitativo e qualitativo, tendo em vista que buscou-se interpretar as informações relacionadas ao objeto do estudo. Quanto ao objetivo, foi descritivo, pois preocupou-se em observar os fatos, registrá-los e analisá-los. O trabalho evidenciou que dos 19 mu-

\footnotetext{
1 Mestre em Administração e Controladoria pela Universidade Federal do Ceará (UFC). Analista de Controle Externo do Tribunal de Contas do Estado do Ceará. Email: vsavelino@hotmail.com

$2 \quad$ PhD em Higher Education e Finanças Públicas pela University of Arizona, Estados Unidos. Pró-Reitor de Gestão de Pessoas da Universidade Federal do Ceará (UFC). Email: marcusmachado@ufc.br

3 Doutora em Educação Brasileira pela Universidade Federal do Ceará (UFC). Email: denisecorrea@ secrel.com.br
} 
nicípios estudados, 16 deles ultrapassaram, em algum momento da série histórica, o limite legal permitido com despesas de pessoal. O ano de 2015 foi o mais crítico, quando nove municípios descumpriram a lei. Em 2017 esse número diminuiu um pouco, chegando a oito - concluindo-se, portanto, que alguns municípios da RMF estão realizando despesas com pessoal acima do limite legal permitido.

Palavras-Chave: Lei de Responsabilidade Fiscal. Despesas com Pessoal. Região Metropolitana de Fortaleza.

\section{ABSTRACT}

The Fiscal Responsibility Law (FRL) has the purpose of preventing and correcting deviations that affect the balance of public accounts, mainly the goals of results between public revenues and expenses. Personnel expenses represent relevant amounts in public accounts, as they consume a considerable share of the budget and can compromise resources allocated to investments. This study analyzed the expenses with personnel of the Executive Power in municipalities from the Metropolitan Region of Fortaleza (MRF) from 2008 to 2017. For such, it evaluated the participation of personnel expenses in relation to the net current revenue of each municipality of MRF and verified whether the amounts spent on personnel changed due to variations in revenue collection. This research problem has a quantitative and qualitative approach since this study interpreted the information related to the purpose of the study and used quantitative data to answer the research problem. As for the study purpose, it was descriptive because it was concerned with observing the facts, recording and analyzing them. Out of the 19 municipalities studied, 16 of them exceeded the legal limit allowed for personnel expenses at some point in the historical series. The year of 2015 was the most critical, as nine municipalities failed to comply with the law. In 2017, that number decreased slightly, reaching eight municipalities, demonstrating that some municipalities of the MRF are incurring in personnel expenses above the legal limit allowed. 
Keywords: Fiscal Responsibility Law (LRF). Personnel expenses. Metropolitan Region of Fortaleza.

Recebido: 24-04-2020

Aprovado: 26-09-2020

\section{INTRODUÇÃO}

A Lei Complementar $\mathrm{n}^{\circ}$ 101, também conhecida como Lei de Responsabilidade Fiscal (LRF), promulgada em maio de 2000, com o objetivo de disciplinar os gastos públicos e impor limites ao endividamento do governo, teve caráter inovador e se tornou um importante instrumento normativo no controle das finanças públicas e na implantação de uma política de gestão fiscal responsável.

A LRF disciplina matérias previstas nos artigos 163 e 169 da Constituição Federal de 1988 e estabelece regras de transparência, controle e fiscalização dos atos de gestão que se aplicam à União, aos estados e municípios de forma irrestrita. Destinada a aprimorar a administração pública, a lei introduziu o conceito de responsabilidade na gestão fiscal buscando combater duas grandes fontes de gastos com o dinheiro público: as despesas com pessoal (DP) e as despesas com pagamento da dívida pública (BRASIL, 1988; BRASIL, 2000).

Em relação ao endividamento, a LRF procura equilibrar permanentemente as contas públicas, determinando que a dívida consolidada líquida não pode ultrapassar a receita líquida corrente na proporção de duas vezes para os estados e o Distrito Federal, e 1,2 vezes para os municípios (GIUBERTI, 2005).

Entre os gastos públicos, os que mais se destacam são os relativos a pessoal, pois comprometem grande parcela do orçamento público. A imposição de limites gerais e específicos para as despesas com pessoal, bem como sublimites para todos os poderes e órgãos independentes na 
estrutura estatal, visa assegurar que o Estado não perca a capacidade de realizar investimentos em saúde, em educação e em segurança, bem como na manutenção e na preservação do patrimônio público, dentre outros, de forma a preservar o bem-estar social (BARBOSA, 2008).

Decorridos 18 anos de vigência da Lei de Responsabilidade Fiscal (LRF), que estabeleceu limites especialmente no que se refere ao comprometimento da receita corrente líquida (RCL) com os gastos com pessoal, torna-se importante pesquisar o comportamento dos gastos com pessoal nos municípios da Região Metropolitana de Fortaleza (RMF) nos últimos dez anos devido à importância que essa despesa representa na economia municipal.

A Região Metropolitana de Fortaleza é uma macrorregião de planejamento do estado do Ceará, a sexta maior região metropolitana do país, composta de 19 municípios que representam mais de $63 \%$ do PIB do estado, dados que demonstram a sua importância econômica (CEARÁ, 2009).

Foi escolhido um período de dez anos pelo intervalo permitir a montagem de uma série histórica para analisar a evolução das variáveis em mais de duas legislaturas municipais. Dessa forma, a pesquisa tem a seguinte questão problema: quais os efeitos da LRF sobre os gastos com pessoal do Poder Executivo nos municípios da Região Metropolitana de Fortaleza no período de 2008 a 2017? A partir da questão norteadora do estudo, o objetivo geral desta pesquisa consiste em analisar os gastos com pessoal do Poder Executivo nos municípios da RMF, no período de 2008 a 2017.

Especificamente, o estudo aqui desenvolvido pretende: identificar a participação das despesas com pessoal em relação à receita corrente líquida de cada município da RMF e verificar se os valores gastos com pessoal sofreram alterações em função das variações de arrecadação de receitas.

Após a Constituição de 1988, os municípios brasileiros passaram a ter elevada importância na execução das políticas públicas e a responder 
por boa parte das demandas por serviços públicos no país. Esse cenário aumentou a pressão sobre as finanças municipais e, devido à escassez de recursos, permitiu que estes municípios ficassem extremamente dependentes dos recursos transferidos dos estados e da União (SANTOS FILHO, 2012).

Sob a perspectiva social, este estudo é relevante perante o interesse público do controle social da gestão pública, uma vez que o gasto excessivo com pessoal restringe a aplicação de recursos em investimentos e em outras despesas essenciais à população, bem como leva ao descumprimento dos limites exigidos pela LRF para uma gestão responsável.

Este estudo foi estruturado em cinco seções, incluindo a presente introdução: a segunda seção apresentou o referencial teórico, abordando assuntos relacionados à receita e despesa pública, à LRF, o contexto de sua criação, os relatórios fiscais, a composição da receita corrente líquida, os limites de gastos com pessoal, os estudos empíricos anteriores e os pressupostos da pesquisa. A terceira seção versou sobre os procedimentos metodológicos utilizados para realização do estudo, a quarta seção trouxe a análise e discussão dos resultados e a quinta e última seção trouxe as considerações finais do trabalho.

\section{LEI DE RESPONSABILIDADE FISCAL (LRF): ASPECTOS DA RECEITA E DA DESPESA PÚBLICA}

Para definição do modelo conceitual que ampara este estudo, apresenta-se uma abordagem sobre receita pública e despesa pública, com foco para as despesas com pessoal, a Lei de Responsabilidade Fiscal (LRF) e, por fim, estudos empíricos anteriores sobre este assunto.

\subsection{Receita pública na LRF}

São requisitos essenciais de responsabilidade na gestão fiscal a previsão, arrecadação e renúncia da receita pública. Considerando que a 
arrecadação de tributos é uma das fontes que financiam o exercício das funções constitucionais e depende da interação de acontecimentos econômicos, políticos e sociais nacionais e internacionais, a omissão em aumentar as possibilidades financeiras do Estado leva à inobservância do princípio da responsabilidade fiscal (BRASIL, 2000).

$\mathrm{O}$ artigo 12 da LRF estabelece os requisitos que deverão ser observados quando da previsão das receitas, tais como as normas técnicas e legais, os efeitos das alterações na legislação, a variação do índice de preços, o crescimento econômico e outros fatores que sejam considerados relevantes, bem como determina que sejam apresentados o demonstrativo da sua evolução nos últimos três exercícios, a projeção para os dois exercícios seguintes àquele a que se referirem e a metodologia de cálculo utilizada.

Conforme explicam Zonatto e Hein (2013), é a partir de uma previsão orçamentária adequada que se torna possível a qualificação dos processos de planejamento dos recursos necessários para a viabilização de obras públicas, capazes de proporcionar bem-estar comum.

A arrecadação e a aplicação da receita pública, que se apresentam como constantes desafios à gestão de finanças públicas municipais, possuem o intuito de atender ao desenvolvimento local, posto que são cada vez maiores as demandas da sociedade. Esse cenário, no entanto, está sofrendo algumas alterações devidas às exigências legais, como a descentralização de atribuições e o maior controle das contas públicas, de acordo com o que determina a LRF (SOARES; FLORES; CORONEL, 2014).

\subsection{Despesa pública na LRF}

Para Mota (2009), a despesa pública consiste na realização de gastos, isso é, na aplicação de recursos financeiros de forma direta para a 
aquisição de meios, bens e serviços que possibilitem a manutenção, o funcionamento e a expansão dos serviços públicos; ou de forma indireta, quando da realização de transferências a terceiros. Essa aquisição dar-se-á com pagamento imediato, quando da execução da despesa à vista, ou a posteriori, implicando na assunção de compromissos.

A despesa pública é tratada na LRF nos artigos 15 ao 24, dispondo inicialmente que a geração de despesa ou assunção de obrigação que não atendam ao disposto nos artigos 16 e 17 serão consideradas não autorizadas, irregulares e lesivas ao patrimônio público. O artigo 16 traz as obrigatoriedades de estimar o impacto orçamentário e financeiro em três exercícios, antes da tomada de decisões política e gerencial que acarretem aumento de despesa, bem como de apresentar a declaração do ordenador de despesa, informando que o aumento tem adequação orçamentária e financeira com a Lei Orçamentária Anual (LOA) e compatibilidade com o Plano Plurianual (PPA) e com a Lei de Diretrizes Orçamentárias (LDO). Todas essas condições caracterizam a ação planejada e transparente tão exigida pela responsabilidade fiscal (BRASIL, 2000).

A despesa obrigatória de caráter continuado é definida no artigo 17 como a despesa corrente derivada de lei, medida provisória ou ato administrativo normativo que determine para o ente a sua execução por um período superior a dois exercícios financeiros. Com isso, o Estado tenta assegurar que as despesas que se destinam ao custeio da atividade pública e que necessitam de continuidade só sejam implementadas se instruídas com o impacto orçamentário-financeiro no exercício a que se referirem e nos dois exercícios seguintes, se compatíveis com as metas de resultados fiscais e se comprovada a origem dos recursos para seu custeio (BRASIL, 2000).

Às despesas com pessoal também se aplicam os condicionantes para a geração de despesas obrigatórias de caráter continuado, conforme dispõe o artigo 21 da LRF, que trata do controle da despesa total com pessoal. Consoante ao referido dispositivo, é nulo de pleno direito o ato que provoque aumento da despesa com pessoal e não atenda as exigências 
dos artigos 16 e 17 dessa lei complementar, e o disposto no inciso XIII do artigo 37 e no $\S 1^{\circ}$ do artigo 169 da Constituição, ou não observe o limite legal de comprometimento aplicado às despesas com pessoal inativo; ou, ainda, o ato de que resulte aumento da despesa com pessoal expedido nos cento e oitenta dias anteriores ao final do mandato do titular dos poderes executivo, legislativo e judiciário, na esferas federal, estadual e municipal (BRASIL, 2000).

\subsection{A lei de responsabilidade fiscal - LRF}

Um estudo realizado por Costa (2008) apresenta a adoção de regras fiscais para controlar os gastos públicos por diversos países, como nos Estados Unidos, onde foram implementadas sucessivas leis para controlar o déficit público, com grandes resultados. Assim, em 1985, foi implementada a Gramm-Rudman-Holings Act, a Lei do Orçamento Equilibrado e de Controle Emergencial do Déficit, que estabelece a redução gradual do déficit em um período de cinco anos. Essa lei determinava o cancelamento de dotações sempre que o déficit projetado ultrapassasse a meta permitida (COSTA, 2008; SANTOS FILHO, 2012).

Em seguida, surgiu em 1990 o Budget Enforcement Act (BEA), a Lei de Cumprimento do Orçamento, aplicada somente ao governo federal, que visava controlar as despesas e receitas, impondo limites anuais e restrições sobre esses gastos. Foi introduzido o mecanismo de corte automático das dotações orçamentárias sempre que as previsões indicassem o não cumprimento das metas de resultado fiscal fixadas pelo congresso (SANTOS FILHO, 2012).

A Comunidade Econômica Europeia (CEE), criada em 1992 por diversos países europeus, foi celebrada por meio do Tratado de Maastrich que possuía status constitucional e, impune dessa informação, há a observância de regras fiscais, limites para dívida pública e déficit orçamentário (SANTOS FILHO, 2012). 
Na Nova Zelândia, surgiu em 1994 o Fiscal Responsibility Act (FRA), a lei de responsabilidade fiscal que valorizou a transparência das contas públicas, tendo como objetivos: uma maior visibilidade das políticas públicas, fiscais e econômicas; o orçamento como uma peça de planejamento em longo prazo; a análise antecipada do impacto agregado do orçamento; a emissão de relatórios fiscais e a apresentação de uma linguagem acessível aos parlamentares e ao cidadão (COSTA, 2008).

No Brasil, o Projeto de Lei de Responsabilidade Fiscal se inspirou nos instrumentos de controle fiscal realizados nos Estados Unidos, Nova Zelândia e Europa, incorporando mecanismos de legislação estrangeira mas adaptando-os à realidade brasileira. $\mathrm{O}$ conceito utilizado pela União Europeia foi adotado pela LRF no Brasil, visto que a pretensão do governo federal era impor limites aos governos subnacionais; inclusive, foi com base nessa experiência que foi criada a Lei $n^{\circ} 10.028$, de 19 de outubro de 2000, que trata dos crimes contra as finanças públicas no Brasil (VAZQUEZ, 2012).

A razão fundamental que levou à criação da Lei de Responsabilidade Fiscal no Brasil foi registrada na exposição de motivos que acompanhou seu projeto de Lei (PLC $\left.n^{\circ} 18 / 1999\right)$, sendo ela a necessidade de instituir processos estruturais de controle do endividamento público, direta e indiretamente (OLIVEIRA, 2015).

Assim, a LRF foi um avanço na legislação brasileira e também uma enorme conquista para a sociedade, pois teve como escopo a implantação de uma política de gestão fiscal responsável ao combater as duas principais fontes de desperdícios de recursos públicos denunciadas pela população em geral: o gasto excessivo com as despesas com pessoal e as despesas excessivas com pagamento do serviço da dívida pública (DOIA, 2016).

Os instrumentos destacados pela LRF para o planejamento do gasto público no âmbito da União, estados, Distrito Federal e municípios são os mesmos já adotados na Constituição federal, quais sejam: o Plano Pluria- 
nual (PPA), a Lei de Diretrizes Orçamentárias (LDO) e a Lei de Orçamento Anual (LOA) (BRASIL, 2000).

Segundo Giuberti (2005), a intenção foi estabelecer a obrigatoriedade de se incluir na LDO um Anexo de Metas Fiscais, que deve conter as previsões de receitas e despesas, bem como os resultados nominal, primário e o montante da dívida pública para o exercício a que se refere a LDO e os dois anos seguintes, além de um anexo de riscos fiscais, que deve avaliar os possíveis fatos que irão impactar nos resultados fiscais estabelecidos para o exercício.

O artigo 54 da LRF dispõe que deve ser apresentado, ao final de cada quadrimestre pelos titulares dos poderes e órgãos, demonstrativos com informações relativas à despesa total com pessoal, dívida consolidada e mobiliária, concessão de garantias, operações de crédito e contra garantias de valores, bem como operações de crédito. No último quadrimestre também serão apresentados os demonstrativos referentes ao montante à disponibilidade de caixa em 31 de dezembro, além das inscrições em Restos a Pagar. Pela quantidade de informações disponibilizadas, esses relatórios são imprescindíveis ao acompanhamento da gestão fiscal, pois demonstram, dentre outros aspectos, o cumprimento dos limites dos gastos implementados pela LRF (BRASIL, 2000).

Um dos conceitos fundamentais constantes na LRF é o da Receita Corrente Líquida (RCL) - que é utilizada como um parâmetro-referência, uma base de cálculo única, prevista na LRF - sobre a qual serão aplicados determinados percentuais para obtenção dos montantes que configurarão valores-limites (pessoal, dívida, operações de crédito, concessão de garantias) (OLIVEIRA, 2015).

De acordo com a LRF, RCL corresponde ao somatório das receitas tributárias de contribuições patrimoniais, industriais, agropecuárias, de serviços, transferências correntes e outras receitas também correntes, deduzidos: a) na União, os valores transferidos aos estados e municípios 
por determinação constitucional ou legal, e as contribuições mencionadas na alínea a do inciso I e no inciso II do artigo 195, e no artigo 239 da Constituição; b) nos estados, as parcelas entregues aos municípios por determinação constitucional; c) na União, nos estados e nos municípios, a contribuição dos servidores para o custeio do seu sistema de previdência e assistência social e as receitas provenientes da compensação financeira citada no $\S 9^{\circ}$ do artigo 201 da Constituição. (BRASIL, 2000).

Serão ainda computados no cálculo da RCL os valores pagos e recebidos em decorrência da Lei Complementar $n^{\circ} 87$, de 13 de setembro de 1996, e do fundo previsto pelo artigo 60 do Ato das Disposições Constitucionais Transitórias; entretanto, não serão considerados na receita corrente líquida do Distrito Federal e dos estados do Amapá e de Roraima os recursos recebidos da União para atendimento das despesas de que trata o inciso $\mathrm{V}$ do $\S 1^{\circ}$ do artigo 19 da LRF (BRASIL, 2000).

Conforme se observa do $\S 3^{\circ}$, do artigo $2^{\circ}$ da LRF, a RCL será apurada somando-se os 12 meses de receita, a do mês de apuração e dos 11 meses imediatamente anteriores a ele, excluídas as duplicidades. Nesse sentido, na composição da RCL deve ser considerado sempre o período de 12 meses, o que não quer dizer que necessariamente deve coincidir com o exercício financeiro (BRASIL, 2000).

Oliveira (2015) descreve que a RCL é um parâmetro-referência, uma base de cálculo única, prevista na LRF sobre a qual serão aplicados determinados percentuais para obtenção dos montantes que configurarão valores-limites (pessoal, dívida, operações de crédito, concessão de garantias).

Para a Secretaria do Tesouro Nacional, o principal objetivo da RCL é servir de parâmetro para o montante da reserva de contingência e para os limites da despesa total com pessoal, da dívida consolidada líquida, das operações de crédito, do serviço da dívida, das operações de crédito por antecipação de receita orçamentária e das garantias do ente da Federação (BRASIL, 2009). 
2.3.1 Limites de gastos com pessoal

A Constituição federal de 1988 limitou as despesas com pessoal, abrangendo os ativos e inativos, em seu artigo 169, determinando que uma lei complementar regulamentasse tal limitação (BRASIL, 1988). A Lei Complementar 101/2000, também conhecida como LRF, preencheu a lacuna deixada pela Constituição federal, regulamentando o artigo 169.

Assim, a LRF adotou como parâmetro de controle da despesa com pessoal a fixação de percentual sobre a Receita Corrente Líquida. O artigo 19 da LRF estabeleceu limites às despesas com pessoal, no âmbito da União, dos estados e dos municípios, criou o chamado limite prudencial, que corresponde a $95 \%$ do total do limite geral. Portanto, o limite prudencial das despesas com pessoal corresponde a 47,5\% da Receita Corrente Líquida da União Federal e 57\%, para os estados e municípios (BRASIL, 2000).

Caso exceda o limite prudencial, a administração pública sujeita-se às restrições previstas no artigo 22 da LRF, sendo-lhe vedada: a concessão de vantagens, aumentos, reajustes ou adequações de remuneração a qualquer título; criar cargos, empregos ou funções, alterar estrutura de carreira que implique aumento de despesas, admissão ou contratação de pessoal, a qualquer título, salvo decorrente de aposentadoria ou falecimento de servidores das áreas de educação, saúde e segurança, dentre outras (BRASIL, 2000).

A partir do conceito do limite prudencial, surgiu ainda o conceito do limite pré-prudencial, ou limite de alerta, que corresponde a $90 \%$ do limite geral, consoante ao mostrado na Tabela 1, sendo atribuição dos tribunais de contas monitorar a observância destes limites em cada quadrimestre do exercício e, conforme o artigo 59 da LRF, alertar o poder ou órgão que tenha ultrapassado esse limite, conforme mostrado na Tabela 1 (BRASIL, 2000). 
Tabela 1: Limites das despesas com pessoal no âmbito da União Federal, estados e municípios

\begin{tabular}{c|c|c|c}
\hline Abragência dos gastos & União Federal & Estados & Municípios \\
\hline Poder Legislativo mais Tribunal de Contas & $2,5 \%$ & $3,0 \%$ & $6,0 \%$ \\
\hline Poder Judiário & $6,0 \%$ & $6,0 \%$ & \\
\hline Poder Executivo & $40,9 \%$ & $49,0 \%$ & $54,0 \%$ \\
\hline Min. Publico & $0,6 \%$ & $2,0 \%$ & \\
\hline $\begin{array}{c}\text { Limite Legal ou máximo das despesas } \\
\text { em relação à Receita Corrente Líquida }\end{array}$ & $50,0 \%$ & $60,0 \%$ & $60,0 \%$ \\
\hline Limite prudencial (95\% do limite legal) & $47,5 \%$ & $57,0 \%$ & $57,0 \%$ \\
\hline Limite pré-prudencial (90\% do limite legal) & $45,0 \%$ & $54,0 \%$ & $54,0 \%$ \\
\hline
\end{tabular}

Observação: Os limites dos Poder Executivo no âmbito dos municípios são: i) Limite legal $=\mathbf{5 4 \%}$;

ii) Limite prudencial ou máximo $=\mathbf{5 1 , 3 0} \%$ e iii) Limite pré-prudencial ou de alerta $=\mathbf{4 8 , 6} \%$

Fonte: Elaborada pelos autores (2018) com base na LRF (BRASIL, 2000).

Caso o gestor ultrapasse os limites definidos na LRF, sem prejuízo das restrições previstas no artigo 22 da LRF, ficará também sujeito às restrições previstas no artigo 23 da mesma lei, que determina a eliminação do excedente nos dois quadrimestres seguintes, sendo pelo menos um terço no primeiro, devendo para tanto adotar as seguintes providências previstas nos $\S 3^{\circ}$ e $\S 4^{\circ}$ do artigo 169 da Constituição Federal: extinção de cargos e funções ou redução dos valores a elas atribuídos, redução temporária de jornada de trabalho e adequação dos vencimentos (BRASIL, 2000).

Por força do artigo 23 da LRF, descumprida a redução no prazo estabelecido para ajuste do montante da despesa com pessoal e enquanto permanecer o excesso, fica vedado ao ente público: receber transferências voluntárias; obter garantias, diretas ou indiretas, de outro ente; contratar operações de crédito, ressalvadas as destinadas ao refinanciamento da dívida mobiliária e as que visem à redução das despesas com pessoal, não se aplicando aos municípios, em caso de queda de receita superior a $10 \% \mathrm{em}$ comparação ao correspondente quadrimestre do exercício financeiro anterior, e desde que esta queda seja justificada por diminuição das transferências recebidas do Fundo de Participação dos Municípios decorrente de 
concessão de isenções tributárias pela União, ou ainda por diminuição das receitas recebidas de royalties e participações especiais (BRASIL, 2000).

Dentre os estudos empíricos desenvolvidos abordando a relação entre a LRF, despesas com pessoal e limites de gastos públicos, destacam-se dois, por guardarem estreita relação com os objetivos do presente estudo: o estudo de Campagnoni e Platt Neto (2014) e o de Souza, Silva e Câmara (2018).

O primeiro estudo teve como objetivo verificar a observância do cumprimento dos limites para despesas com pessoal estabelecidas na Lei de Responsabilidade Fiscal, entre poderes e órgãos da União, no período de 2000 a 2013. Como resultados, os autores verificaram que a União, incluindo os poderes e órgãos analisados, cumpriu os limites máximo, prudencial e de alerta instituídos pela LRF em todos os anos analisados. Constatou-se também a evolução das variáveis no período delimitado para isso, procedeu-se um ajuste monetário com base no Índice de Preços ao Consumidor Amplo. Verificou-se que a despesa total com pessoal cresceu 42,74\% entre 2000 e 2013, e a RCL cresceu 99,45\% no mesmo período. Portanto, os gastos com pessoal evoluíram em menores proporções que a RCL (CAMPAGNONI; PLATT NETO, 2014).

O segundo estudo teve como objetivo analisar a situação das despesas com pessoal nas capitais nordestinas, no período de 2006 a 2016, em relação aos limites impostos pela Lei de Responsabilidade Fiscal e a receita corrente total, e os autores concluíram que as despesas com pessoal aumentaram mais que suas fontes de recursos levando a um desequilíbrio das contas públicas. $O$ resultado do referido estudo sugere que houve uma diminuição de recursos para serem aplicados nos demais grupos de natureza de despesa (SOUZA; SILVA; CÂMARA, 2018).

Com base nestes estudos, esta pesquisa parte dos seguintes pressupostos: 1) os municípios da RMF estão gastando acima do limite legal permitido com despesas de pessoal; 2) a arrecadação da receita municipal 
vem sendo reduzida no período estudado acarretando o não cumprimento dos limites com pessoal; 3) as despesas com pessoal não variam em função das receitas arrecadadas; 4) as despesas com pessoal aumentam nos anos em que ocorrem eleições municipais.

\section{METODOLOGIA}

Este estudo teve abordagem predominantemente quantitativa, pois permitiu identificar quantos municípios cumpriram os limites das despesas com pessoal previstos na LRF utilizando-se de ferramentas de estatística descritiva. Também fez uso da abordagem qualitativa, posto que buscou-se interpretar as informações e dados relacionados ao objeto do estudo, que são as receitas e despesas, e compreender as suas variações no período estudado.

Ademais, o estudo se caracteriza como descritivo (GIL, 2017), pois objetivou analisar os gastos com pessoal do Poder Executivo nos municípios da Região Metropolitana de Fortaleza no período de 2008 a 2017.

Quanto às técnicas de coleta de dados, este estudo foi bibliográfico porque teve como objeto o levantamento de referências teóricas já analisadas e publicadas por meios escritos e eletrônicos, como livros, artigos científicos, páginas de websites, com o intuito de coletar a base teórica do assunto central do trabalho, e foi documental porque utilizou-se da legislação que dá fundamentação legal ao assunto, bem como os relatórios de acompanhamento gerencial e relatórios de gestão fiscal emitidos pelo Tribunal de Contas do Estado e disponibilizados nos portais da transparência dos municípios estudados, em que constam, dentre outras, informações sobre receitas, despesas, investimentos, e atendimento dos limites legais. Foi realizada também pesquisa no Anuário Estatístico do Ceará - 2016, publicado pelo Instituto de Pesquisa e Estratégia Econômica do Ceará (IPECE). 
O estudo abrangeu a análise dos gastos com pessoal do Poder Executivo no âmbito dos 19 municípios que compõem a Região Metropolitana de Fortaleza - RMF, no período de 2008 a 2017. A RMF foi escolhida para realização desse estudo por ser uma macrorregião de planejamento do estado do Ceará, sendo Fortaleza a cidade líder na condução dos processos sociais, políticos e econômicos.

Para a abordagem quantitativa do estudo foram utilizados os 19 municípios da RMF; entretanto, para a análise descritiva dos dados, dentre estes 19 municípios, foram selecionados apenas quatro: os dois melhores e os dois piores no ranking. Para o ranqueamento, o critério utilizado foi o de proximidade dos limites dos gastos com pessoal consoante a LRF. Assim, o parâmetro desta métrica foi o indicador definido pela própria LRF, qual seja: despesa com pessoal/receita líquida corrente. Portanto, quanto mais baixo for este indicador, melhor será o desempenho do município e, quanto mais elevado, pior será o desempenho do município no que concerne à observância do limite destes gastos de pessoal.

Conforme consulta às respectivas leis orçamentárias, o orçamento dos 19 municípios que compõem a região totaliza $\mathrm{R} \$ 11.426 .413 .946,00$, representando cerca de $48 \%$ do orçamento de todos os municípios do estado do Ceará ( $\mathrm{R} \$ 24.010 .812 .614,00)$ para o exercício de 2018.

A coleta dos dados iniciou em março de 2018 e foi encerrada em setembro de 2018, e teve como objeto os dados em valores monetários inerentes a: receita corrente líquida, receitas arrecadadas por município, receitas de transferências e despesas com pessoal em cada exercício, para cálculo do limite prudencial, pré-prudencial, na forma da Tabela 1 deste trabalho e do limite efetivo, assim entendido como sendo o da relação entre a despesa efetiva e a receita corrente líquida.

A coleta teve como fonte os Relatórios de Acompanhamento Gerencial - REAGE dos exercícios de 2008 a 2017, extraídos do portal da transparência dos municípios, disponível no site do Tribunal de Contas do Estado do Ceará, uma vez que apresenta dados de caráter informativo sobre o desempenho da administração pública municipal, permitindo 
identificar a observância dos limites ano a ano, bem como calcular a média dos municípios no período de dez anos - objeto do exame - que serviu de base para a apresentação do ranking dos municípios no que concerne à observância dos limites das despesas com pessoal para o Poder Executivo, no âmbito dos municípios, consoante à LRF.

A partir do ranking, apresentado na seção de análise dos resultados, foi possível identificar os dois melhores e os dois piores municípios, para os quais foram feitas as análises com abordagem qualitativa, mediante a apresentação de tabelas para cada um dos quatro municípios, apresentando os valores das despesas com pessoal e das receitas e respectivos percentuais das despesas em relação à receita corrente líquida, ano a ano, ao longo do referido período, de modo a permitir analisar se as variações das receitas resultaram oscilações nas despesas com pessoal. Para cada um destes quatro municípios, foi também elaborado um gráfico de modo a evidenciar a evolução das variáveis do estudo, permitindo, assim, a análise longitudinal do comportamento destas variáveis.

De acordo com os Relatórios de Acompanhamento Gerencial - REAGE, considera-se como receitas arrecadadas (RA) as receitas orçamentárias pertencentes ao poder público, tais como: receitas tributárias, receitas de transferências (RT), receitas de capital, receitas de serviços, receitas patrimoniais e outras.

Foram consideradas na análise as seguintes variáveis: o período em que ocorreram eleições municipais, o grau de dependência de cada município das transferências de recursos de outros entes, as variações nas receitas arrecadadas, o crescimento com gastos em educação, dentre outros.

\section{ANÁLISE DOS RESULTADOS}

Pode ser observado, na Tabela 2, os percentuais das despesas com pessoal em relação à RCL dos municípios da RMF, organizados em um ranking decrescente da média desses valores de 2008 a 2017, identifican- 
do quem ultrapassou o limite de alerta, o prudencial, o limite máximo, e o período que ocorreu.

Comparando-se os anos de 2008 e 2009, verifica-se um crescimento médio do indicador DP/RCL na ordem de $16,9 \%$, em que 12 municípios atingiram os limites pré-prudencial ou o limite prudencial - com destaque para os municípios de Pacatuba, que ficou muito próximo do limite máximo, ao atingir 53,77\%, e São Luís do Curu, com 55,56\%. Em 2011 já somavam cinco os municípios atingindo o limite de alerta, cinco o limite prudencial e dois ultrapassando o limite máximo; isso significa que, dos 19 municípios estudados, 12 já ultrapassavam pelo menos um dos limites dispostos na LRF.

Nos anos de 2008, 2012 e 2016 aconteceram eleições municipais. Em 2012 verifica-se um aumento na média anual do indicador DP/RCL, bem como na quantidade de municípios que não observaram os limites legais da LRF, em relação a 2011. Em 2016, apesar da pequena queda na média anual dos gastos, verifica-se o aumento de mais um município a não observar os limites, em relação a 2015. Em relação a 2008, não foi possível realizar o comparativo.

Tabela 2: Evolução do \% Despesa com Pessoal/ Receita Corrente Líquida, de 2008 a 2017

\begin{tabular}{|c|c|c|c|c|c|c|c|c|c|c|c|c|}
\hline Rank & Município & 2008 & 2009 & 2010 & 2011 & 2012 & 2013 & 2014 & 2015 & 2016 & 2017 & Média \\
\hline $19^{\circ}$ & Guaiúba & 46,55 & 53,08 & 53,53 & 53,77 & 53,30 & 61,32 & 59,01 & 60,77 & 54,64 & 66,27 & 56,22 \\
\hline $18^{\circ}$ & Pacajus & 32,73 & 50,54 & 53,99 & 55,09 & 68,59 & 53,61 & 56,60 & 59,55 & 57,51 & 61,36 & 54,96 \\
\hline $17^{\circ}$ & Maranguape & 51,00 & 53,09 & 51,07 & 51,87 & 53,14 & 56,65 & 50,12 & 54,67 & 57,02 & 66,45 & 54,51 \\
\hline $16^{\circ}$ & Paraipaba & 39,95 & 51,16 & 50,54 & 50,70 & 60,12 & 61,45 & 53,12 & 57,43 & 52,52 & 64,28 & 54,13 \\
\hline $15^{\circ}$ & Pacatuba & 47,95 & 53,77 & 54,73 & 55,26 & 55,66 & 50,54 & 55,92 & 55,05 & 53,98 & 55,10 & 53,80 \\
\hline $14^{\circ}$ & $\begin{array}{l}\text { São Luís } \\
\text { do Curu }\end{array}$ & 49,45 & 55,46 & 52,28 & 51,69 & 52,72 & 59,54 & 54,02 & 58,16 & 54,29 & 49,42 & 53,70 \\
\hline $13^{\circ}$ & Trairi & 42,96 & 52,68 & 53,71 & 49,68 & 51,32 & 53,17 & 54,34 & 52,50 & 53,11 & 55,49 & 51,89 \\
\hline $12^{\circ}$ & Paracuru & 34,87 & 43,41 & 43,41 & 48,56 & 54,82 & 58,27 & 65,73 & 63,08 & 59,00 & 45,36 & 51,65 \\
\hline $11^{\circ}$ & Aquiraz & 49,32 & 50,35 & 48,98 & 47,46 & 53,54 & 52,98 & 54,64 & 54,21 & 52,08 & 49,26 & 51,28 \\
\hline $10^{\circ}$ & Horizonte & 39,29 & 47,95 & 47,52 & 47,14 & 52,11 & 49,39 & 53,94 & 53,54 & 54,33 & 61,22 & 50,64 \\
\hline
\end{tabular}


Tabela 2: Evolução do \% Despesa com Pessoal/ Receita Corrente Líquida, de 2008 a 2017 (continuação)

\begin{tabular}{c|c|c|c|c|c|c|c|c|c|c|c|c}
\hline $9^{\circ}$ & Cascavel & 42,94 & 52,05 & 49,08 & 53,52 & 57,03 & 50,15 & 50,00 & 48,56 & 50,55 & 52,09 & 50,60 \\
\hline $8^{\circ}$ & Itaitinga & 46,01 & 52,17 & 48,22 & 50,51 & 51,90 & 54,16 & 50,80 & 43,70 & 50,25 & 54,03 & 50,18 \\
\hline $7^{\circ}$ & Chorozinho & 42,05 & 50,84 & 47,17 & 52,40 & 57,48 & 55,31 & 54,00 & 53,21 & 48,22 & 24,72 & 48,54 \\
\hline $6^{\circ}$ & Maracanaú & 42,41 & 47,58 & 45,69 & 40,63 & 50,94 & 52,03 & 48,65 & 55,82 & 48,98 & 49,72 & 48,25 \\
\hline $5^{\circ}$ & Caucaia & 33,14 & 43,44 & 47,08 & 50,83 & 50,46 & 51,74 & 49,95 & 53,59 & 47,76 & 52,77 & 48,08 \\
\hline $4^{\circ}$ & Pindoretama & 37,82 & 50,52 & 51,65 & 49,58 & 52,37 & 53,14 & 50,38 & 48,67 & 45,83 & 38,18 & 47,81 \\
\hline $3^{\circ}$ & Eusébio & 37,46 & 39,98 & 45,75 & 48,01 & 50,07 & 45,98 & 51,79 & 46,71 & 54,48 & 51,18 & 47,14 \\
\hline $2^{\circ}$ & Fortaleza & 44,55 & 45,34 & 43,03 & 42,09 & 43,67 & 50,08 & 45,98 & 43,77 & 45,44 & 42,09 & 44,60 \\
\hline $1^{\circ}$ & $\begin{array}{c}\text { São Gonçalo } \\
\text { do Amarante }\end{array}$ & 27,57 & 27,74 & 39,37 & 41,45 & 54,39 & 48,27 & 45,00 & 45,88 & 49,55 & 50,86 & 43,01 \\
\hline & $\begin{array}{c}\text { Média anual } \\
\text { Qde. muni- } \\
\text { cípios que } \\
\text { observaram } \\
\text { os limites }\end{array}$ & 41,47 & 48,48 & 48,78 & 49,49 & 53,88 & 53,57 & 52,84 & 53,10 & 52,08 & 52,10 & \\
\hline & 16 & 7 & 9 & 7 & 1 & 2 & 2 & 5 & 4 & 4 & \\
\hline $\begin{array}{c}\text { Qde. municí- } \\
\text { pios que não } \\
\text { observaram } \\
\text { os limites }\end{array}$ & 3 & 12 & 10 & 12 & 18 & 17 & 17 & 14 & 15 & 15 & \\
\hline
\end{tabular}

Legenda de cores do destaque

\begin{tabular}{|l|l|}
\hline Limite pré-prudencial ou de alerta $(48,60 \%$ a $51,29 \%)$ \\
\hline Limite prudencial (51,30\% a $53,99 \%)$ \\
\hline Limite máximo (54\% ou acima) \\
\hline
\end{tabular}

Fonte: Dados da pesquisa (2018) obtidos a partir do Portal da Transparência dos Municípios.

Fazendo um comparativo entre os anos eleitorais, observa-se, em 2012, um crescimento de $29,9 \%$ da média anual do indicador em relação ao ano de 2008, quando a média anual alcançou seu percentual mais alto da série $-53,88 \%$. Nesse ano, oito municípios alcançaram o limite prudencial e sete ultrapassaram o limite máximo legal. Em 2016, apesar do crescimento da média anual e da quantidade dos municípios que descumpriram os limites legais em relação a 2008, verifica-se uma queda em ambos os valores em comparação ao ano de 2012.

Observa-se na Tabela 2 que, em 2015, 14 municípios excederam pelo menos um dos limites e, em 2016 e em 2017, 15 municípios excederam tais limites. Cabe destacar que, em 2015, nove municípios já estavam 
com gastos acima do limite máximo de $54 \%$ - portanto, quase metade de toda RMF descumprindo o limite legal. Em 2016 e 2017, os percentuais anuais médios das despesas foram de 52,08\% e 52,10\%, respectivamente, ficando muito próximos da média anual de 53,10\%, em 2015. Verifica-se que vários municípios da RMF realizaram despesas com pessoal acima do limite legal permitido de 2008 a 2017 e que essas despesas aumentaram nos anos em que ocorreram eleições municipais.

De acordo com a média anual, verificada na Tabela 2, restou comprovada uma expansão do indicador DP/RCL no período estudado de mais de $25 \%$, passando de $41,47 \%$, em 2008, quando somente três municípios atingiram o limite de alerta, para 52,10\%, em 2017, quando oito municípios ultrapassaram o limite máximo. Constata-se que os municípios estudados estão gastando acima do limite legal permitido.

Pode-se constatar que os dois melhores municípios foram São Gonçalo do Amarante e Fortaleza, com percentual médio no período de 43,01\% e 44,60\%, respectivamente, e os dois piores municípios foram Guaiúba e Pacajus, com percentual médio no período de 56,22\% e 54,96\%, respectivamente. Assim, esses quatro municípios serão objeto de análise mais pormenorizada dos itens que compuseram o percentual das despesas de pessoal em relação às receitas correntes líquidas.

Tendo como parâmetro apenas o limite máximo de 54\% da RCL, dentre os 19 municípios da RMF, apenas Caucaia, Pindoretama e Fortaleza estiveram abaixo dos limites da LRF em todos os anos do período examinado. Verifica-se ainda, na Tabela 2, que dez municípios descumpriram o limite máximo por mais de um exercício consecutivo, comprovando que não foram adotadas medidas para eliminar o percentual excedente, o que comprova o descumprimento sistemático da lei.

Analisando os municípios com os melhores e com os piores desempenhos na observância dos limites das despesas de pessoal, consoante à LRF, foram observados o comportamento das seguintes variáveis dos referidos municípios no período examinados: i) receita arrecadada (RA); ii) receitas de 
transferências (RT); iii) despesas com pessoal (DP); e iv) percentual das despesas com pessoal em relação à Receita Corrente Líquida (DP/RCL).

De acordo com os dados apresentados na Tabela 2, verifica-se que São Gonçalo do Amarante foi o município que obteve melhor desempenho na relação DP/RCL, com uma média de 43,01\% no período de 2008 a 2017. Nos quatro primeiros anos da série (2008 a 2011), o percentual manteve-se bem baixo, entretanto, sempre crescente, com o menor valor em 2008 (27,57\%) e chegando a 41,45\% em 2011.

Tabela 3: Dados do Município de São Gonçalo do Amarante de 2008 a 2017 (em R\$)

\begin{tabular}{c|c|c|c|c}
\hline Ano & $\begin{array}{c}\text { Receita } \\
\text { Arrecadada (RA) }\end{array}$ & $\begin{array}{c}\text { Receitas de } \\
\text { Transferências (RT) }\end{array}$ & $\begin{array}{c}\text { Despesa com } \\
\text { Pessoal (DP) }\end{array}$ & \%DP/RCL \\
\hline 2008 & $58.346 .182,30$ & $40.928 .395,70$ & $15.648 .447,00$ & $\mathbf{2 7 , 5 7}$ \\
\hline 2009 & $74.259 .105,99$ & $44.570 .079,36$ & $20.549 .385,26$ & $\mathbf{2 7 , 7 4}$ \\
\hline 2010 & $81.502 .264,69$ & $43.609 .110,67$ & $30.677 .644,47$ & $\mathbf{3 9 , 3 7}$ \\
\hline 2011 & $108.797 .023,90$ & $53.861 .180,02$ & $42.144 .408,80$ & $\mathbf{4 1 , 4 5}$ \\
\hline 2012 & $95.508 .081,54$ & $60.047 .704,58$ & $50.564 .724,13$ & $\mathbf{5 4 , 3 9}$ \\
\hline 2013 & $133.461 .111,14$ & $73.524 .311,26$ & $61.357 .039,77$ & $\mathbf{4 8 , 2 7}$ \\
\hline 2014 & $193.453 .388,92$ & $82.088 .760,23$ & $83.046 .265,46$ & $\mathbf{4 5 , 0 0}$ \\
\hline 2015 & $245.742 .117,41$ & $99.651 .625,43$ & $101.651 .008,07$ & $\mathbf{4 5 , 8 8}$ \\
\hline 2016 & $247.153 .462,67$ & $129.820 .384,23$ & $113.180 .259,80$ & $\mathbf{4 9 , 5 5}$ \\
\hline 2017 & $234.153 .080,53$ & $147.844 .512,45$ & $111.699 .793,47$ & $\mathbf{5 0 , 8 6}$ \\
\hline$\Delta \%$ & 301,3 & 261,2 & 613,8 & $\mathbf{8 4 , 5}$ \\
\hline $2008 / 2017$ & & & & \\
\hline
\end{tabular}

Legenda de cores do destaque

\begin{tabular}{|l|l|}
\hline Limite pré-prudencial ou de alerta $(48,60 \%$ a $51,29 \%)$ \\
\hline Limite prudencial $(51,30 \%$ a $53,99 \%)$ \\
\hline Limite máximo (54\% ou acima)
\end{tabular}

Fonte: Elaborada pelos autores (2018), com dados do Portal da Transparência dos Municípios.

Em 2012, o município atingiu o pico da série histórica ao exceder o limite máximo da LRF, com 54,39\%. Nesse ano, a diminuição nas receitas arrecadadas em relação ao ano anterior se deveu à baixa arrecadação 
das receitas tributárias, conforme informações extraídas do Relatório de Acompanhamento Gerencial (REAGE) do município, pois, mesmo havendo um aumento nas receitas de transferências de $11 \%$ em relação ao ano anterior, elas não foram suficientes para cobrir o aumento das despesas com pessoal na ordem de $20 \%$, o que levou o município ao descumprimento do limite legal.

Em 2017, novamente, se verificou uma queda nas receitas arrecadadas, embora as receitas de transferências tenham crescido $13 \%$ em relação a 2016. Nesse ano, as despesas com pessoal também caíram, mas não o suficiente para diminuir o comprometimento das receitas com esses gastos, que ficaram no limite de alerta ou pré-prudencial.

Observa-se, portanto, que as RA aumentaram 301,3\% em São Gonçalo do Amarante no período estudado; as RT apresentaram um crescimento inferior às RA, com apenas $261,2 \%$; no entanto, as DP aumentaram $613,8 \%$, isso é, mais do que o dobro do valor da arrecadação, o que justifica o aumento do \%DP/RCL.

O crescimento das despesas com pessoal na ordem de $613,8 \%$, puxada principalmente pelas despesas com pessoal da educação que cresceram 529\%, conforme informações extraídas do REAGE desse município.

Cabe ainda observar que, em São Gonçalo do Amarante, as receitas de transferências respondem por mais de 50\% das receitas arrecadadas, confirmando a dependência do município a recursos externos; entretanto, a partir de 2013, verificou-se um afastamento entre as curvas de receitas arrecadadas e receitas de transferências, causada pelo aumento nas arrecadações próprias, conforme informações extraídas do REAGE, demonstrando a diminuição de dependência do município em relação às transferências voluntárias, o que pode ser confirmado pelo Gráfico 1, que mostra os valores destas variáveis ao longo do tempo examinado (CEARÁ, 2018). 
Gráfico 1: Evolução da receita arrecadada, receita de transferência e despesa com pessoal de São Gonçalo do Amarante de 2008 a 2017

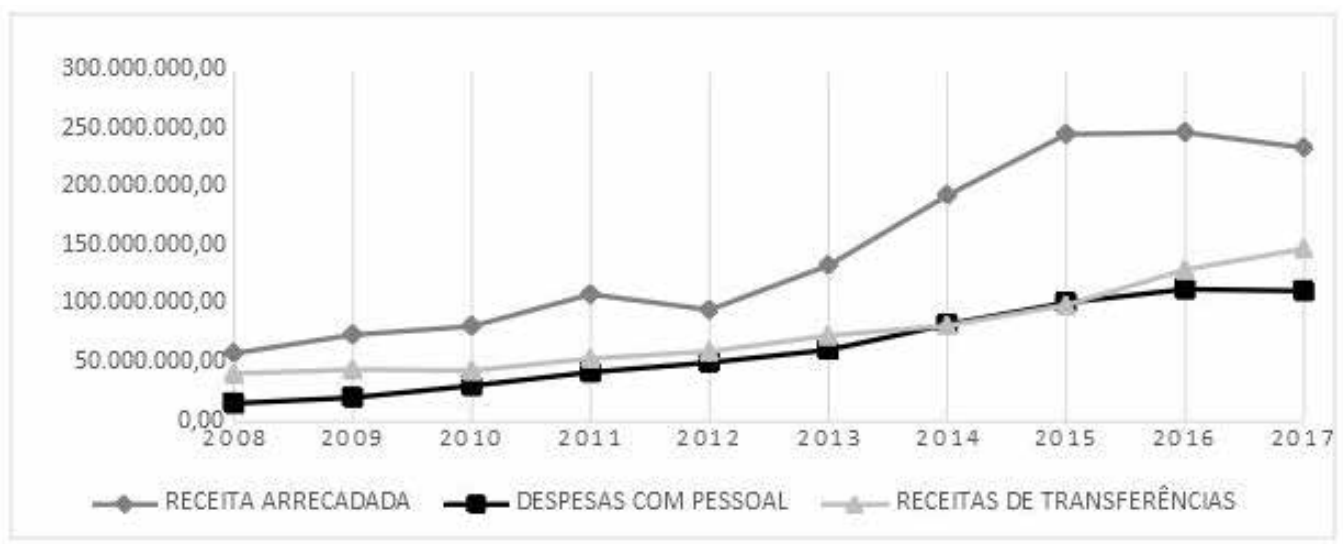

Fonte: Elaborado pelos autores (2018), com dados do Portal da Transparência dos Municípios.

O segundo melhor desempenho ficou com o município de Fortaleza. De acordo com a Tabela 4, observou-se que as RA e as RT foram sempre crescentes, com exceção do ano de 2013, quando apresentou uma pequena queda, tanto na RA como na RT, demonstrando uma estreita relação entre elas. Ressalta-se que no período de 2008 a 2017, observou-se um aumento de $122,7 \%$ das RA, de $101,3 \%$ para as RT e $135,9 \%$ para as DP.

Tabela 4: Dados do Município de Fortaleza, de 2008 a 2017 (em R\$)

\begin{tabular}{c|c|c|c|c}
\hline Ano & $\begin{array}{c}\text { Receita } \\
\text { Arrecadada (RA) }\end{array}$ & $\begin{array}{c}\text { Receitas de } \\
\text { Transferências (RT) }\end{array}$ & $\begin{array}{c}\text { Despesa com } \\
\text { Pessoal (DP) }\end{array}$ & \%DP/RCL \\
\hline 2008 & $2.884 .184 .618,00$ & $1.858 .093 .859,01$ & $1.108 .831 .456,93$ & 44,55 \\
\hline 2009 & $3.009 .012 .841,44$ & $1.999 .686 .729,20$ & $1.177 .867 .446,75$ & 45,34 \\
\hline 2010 & $3.443 .635 .386,61$ & $2.215 .406 .762,81$ & $1.303 .874 .921,09$ & 43,03 \\
\hline 2011 & $4.040 .205 .794,65$ & $2.572 .639 .710,17$ & $1.483 .785 .552,12$ & 42,09 \\
\hline 2012 & $4.665 .067 .029,35$ & $2.863 .433 .518,97$ & $1.753 .148 .630,60$ & 43,67 \\
\hline 2013 & $4.529 .634 .629,65$ & $2.830 .296 .648,47$ & $1.933 .356 .561,35$ & $\mathbf{5 0 , 0 8}$ \\
\hline 2014 & $5.319 .789 .994,90$ & $3.143 .487 .094,94$ & $2.092 .231 .280,05$ & 45,98 \\
\hline 2015 & $5.909 .113 .079,93$ & $3.313 .167 .475,73$ & $2.289 .134 .911,74$ & 43,77 \\
\hline
\end{tabular}


Tabela 4: Dados do Município de Fortaleza, de 2008 a 2017 (em R\$) (continuação)

\begin{tabular}{c|c|c|c|c}
\hline 2016 & $6.254 .158 .699,88$ & $3.623 .133 .605,92$ & $2.466 .899 .535,28$ & 45,44 \\
\hline 2017 & $6.424 .138 .511,45$ & $3.740 .714 .768,76$ & $2.616 .129 .123,51$ & 42,09 \\
\hline$\Delta \% 2008 / 2017$ & 122,7 & 101,3 & 135,9 & $-5,5$ \\
\hline
\end{tabular}

Legenda de cores do destaque

\begin{tabular}{|l|l}
\hline Limite pré-prudencial ou de alerta $(48,60 \%$ a $51,29 \%)$ \\
\hline Limite prudencial $(51,30 \%$ a $53,99 \%)$ \\
\hline Limite máximo (54\% ou acima) \\
\hline
\end{tabular}

Fonte: Elaborada pelos autores (2018) com dados do Portal da Transparência dos Municípios.

Após o ano de 2014, marcado pela crise econômica do país, o crescimento das receitas ocorreu sempre em percentuais menores em relação ao ano anterior; no entanto, as despesas com pessoal obtiveram um crescimento mais acentuado devido principalmente ao aumento das despesas com pessoal da educação. Comparando o ano de 2017 em relação a 2008 , enquanto as despesas com pessoal de forma geral cresceram cerca de $135,9 \%$, as despesas com pessoal da educação cresceram cerca de $250 \%$ - demonstrando o impacto de uma na outra, conforme informações extraídas do REAGE deste município.

Verifica-se no Gráfico 2 que, ao longo da série, o Município passou a depender menos das transferências voluntárias, que passou de $64 \%$, em 2008, para 58\%, em 2017, em relação às receitas arrecadadas. Isso significa que Fortaleza está desenvolvendo aos poucos sua capacidade arrecadatória. Esse fato pode ser mais bem visualizado, a partir de 2013, no crescimento da curva da receita arrecadada em relação às demais. 
Gráfico 2 - Evolução da receita arrecadada, receita de transferência e despesa com pessoal em Fortaleza, de 2008 a 2017

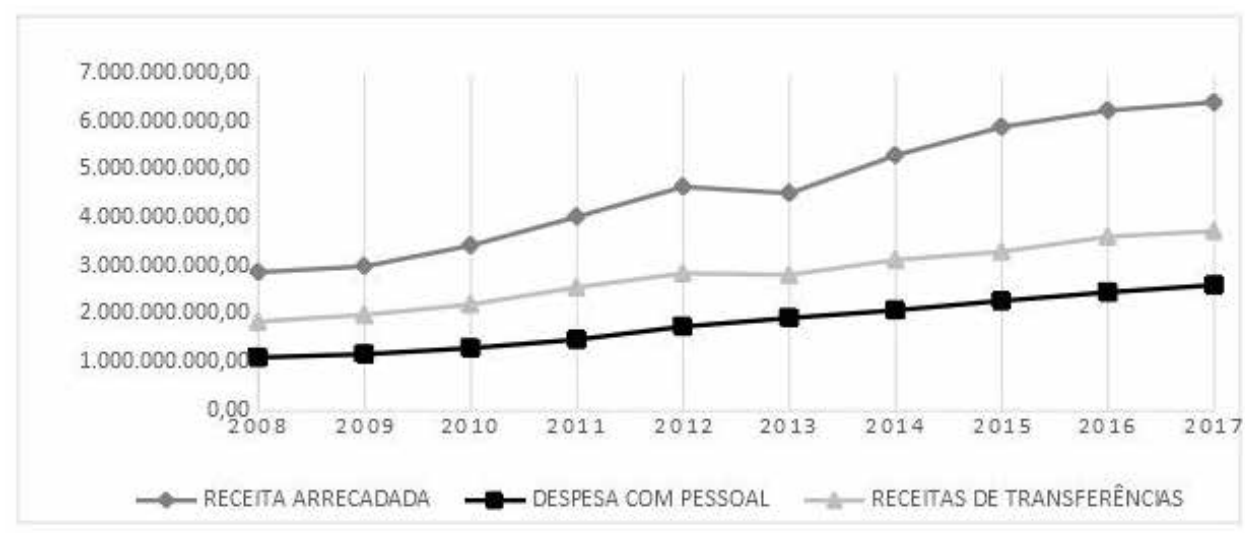

Fonte: Elaborado pelos autores (2018) com dados do Portal da Transparência dos Municípios.

Os dois municípios com pior desempenho no cumprimento dos limites com gastos com pessoal foram Guaiúba e Pacajus, que, conforme apresentado na Tabela 2, só estiveram abaixo dos limites da LRF no ano de 2008.

Verifica-se na Tabela 5 que Guaiúba excedeu o limite prudencial (mais de 95\% do limite máximo) em 2009, sugerindo que o município não implantou os mecanismos necessários para reversão da situação para evitar o descumprimento das metas estabelecidas, tendo em vista que, nos anos seguintes (2010, 2011 e 2012), continuou com os valores do indicador acima do limite prudencial. Essa situação agravou-se em 2013, quando o referido município ultrapassou o limite máximo de 54\% e assim permaneceu até 2017, último ano da série histórica. 
Tabela 5: Dados do município de Guaiúba, de 2008 a 2017 (em R\$)

\begin{tabular}{c|c|c|c|c}
\hline Ano & $\begin{array}{c}\text { Receita } \\
\text { Arrecadada } \\
\text { (RA) }\end{array}$ & $\begin{array}{c}\text { Receitas de } \\
\text { Transferências } \\
(\mathbf{R T})\end{array}$ & $\begin{array}{c}\text { Despesa com } \\
\text { Pessoal (DP) }\end{array}$ & \%DP/RCL \\
\hline 2008 & $23.456 .652,48$ & $21.459 .708,68$ & $9.611 .164,41$ & 46,55 \\
\hline 2009 & $23.262 .283,49$ & $22.472 .910,25$ & $11.761 .574,21$ & 53,08 \\
\hline 2010 & $28.106 .637,19$ & $25.931 .503,64$ & $13.987 .011,19$ & 53,53 \\
\hline 2011 & $33.531 .239,51$ & $33.643 .298,61$ & $17.483 .076,19$ & 53,77 \\
\hline 2012 & $35.025 .150,11$ & $34.463 .083,89$ & $17.859 .335,99$ & 53,30 \\
\hline 2013 & $39.777 .573,47$ & $39.225 .945,83$ & $23.604 .705,99$ & $\mathbf{6 1 , 3 2}$ \\
\hline 2014 & $44.019 .129,23$ & $42.749 .469,28$ & $24.627 .624,94$ & $\mathbf{5 9 , 0 1}$ \\
\hline 2015 & $49.546 .087,19$ & $45.549 .119,88$ & $26.720 .971,08$ & $\mathbf{6 0 , 7 7}$ \\
\hline 2016 & $55.645 .283,23$ & $52.288 .797,93$ & $27.288 .007,79$ & $\mathbf{5 4 , 6 4}$ \\
\hline 2017 & $55.147 .274,88$ & $48.950 .563,92$ & $31.212 .232,10$ & $\mathbf{6 6 , 2 7}$ \\
\hline$\Delta \% 2008 / 2017$ & $135,1 \%$ & $128,1 \%$ & $224,7 \%$ & $\mathbf{4 2 , 4 \%}$ \\
\hline
\end{tabular}

Legenda de cores do destaque

\begin{tabular}{l|l}
\hline & Limite pré-prudencial ou de alerta $(48,60 \%$ a $51,29 \%)$ \\
\hline & Limite prudencial $(51,30 \%$ a $53,99 \%)$ \\
\hline & Limite máximo (54\% ou acima) \\
\hline
\end{tabular}

Fonte: Elaborada pelos autores (2018) com dados do Portal da Transparência dos Municípios.

Em 2017, ano em que o município chegou a $66,27 \%$ de comprometimento da RCL com DP, verificou-se uma queda nominal nas receitas em relação ao ano anterior causada principalmente pela queda nas transferências recebidas, que representaram cerca de $88 \%$ de toda a arrecadação, demonstrando um elevado grau de dependência externa de recursos. No mesmo ano, as despesas com pessoal cresceram cerca de 14\% em relação a 2016, o que justifica o alto índice de comprometimento.

De acordo com o Relatório de Acompanhamento Gerencial do município, a arrecadação tributária girou em torno de 2\% (R\$ 1.224.684,00 em 2017) das receitas arrecadadas - um valor irrisório, sendo composta principalmente pelo Imposto de Renda Retido na Fonte (IRRF) e do Imposto Sobre Serviços (ISS). A arrecadação do Imposto de Propriedade 
Territorial Urbana (IPTU) é mínima, cerca de 1\% do total arrecadado, totalizando em 2017 o valor de R\$12.021,00 (CEARÁ, 2018).

No Gráfico 3 observam-se as curvas das RA e das RT bem próximas, configurando a alta representatividade dos recursos de terceiros no município, demonstrando que a arrecadação própria é muito baixa.

\section{Gráfico 3: Evolução da receita arrecadada, receita de transferência e despesa} com pessoal em Guaiúba, de 2008 a 2017

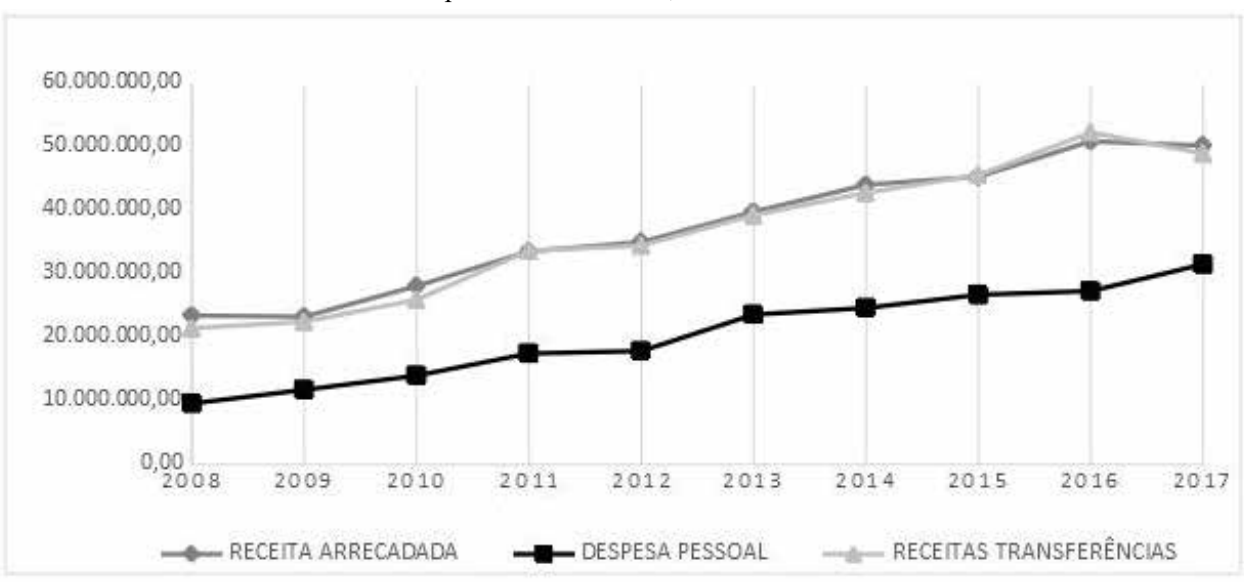

Fonte: Elaborado pelos autores (2018), com dados do Portal da Transparência dos Municípios.

Pacajus foi o segundo município com o pior desempenho. Na Tabela 6 é possível observar que, a exemplo de Guaiúba, o município só ficou abaixo dos limites da LRF em 2008. Em 2009 atingiu o limite de alerta, em 2010, o limite prudencial e, em 2011 e 2012, excedeu o limite máximo, retornando ao limite prudencial em 2013. Em 2014, voltou a exceder o limite máximo, permanecendo nessa condição até 2017, último ano da série histórica, revelando que o município não adotou as medidas necessárias para o controle das despesas de pessoal.

Na Tabela 6 verifica-se que, em 2013, as DP sofreram uma retração ajudada pela queda nas despesas com pessoal da educação (DPE), o que favoreceu a diminuição no percentual da DP/RCL. As DPE representaram, em dez anos, $51 \%$ das DP, conforme informações obtidas no Rela- 
tório de Acompanhamento Gerencial do município. Em 2017, embora as despesas com pessoal tenham apresentado um pequeno aumento, houve um corte substancial nas despesas com pessoal da educação que, caso não tivesse ocorrido, aumentaria mais ainda o percentual das receitas consumidas para pagá-las (CEARÁ, 2018).

Tabela 6: Dados do município de Pacajus, de 2008 a 2017 (em R\$)

\begin{tabular}{c|c|c|c|c|}
\hline Ano & $\begin{array}{c}\text { Receita } \\
\text { Arrecadada (RA) }\end{array}$ & $\begin{array}{c}\text { Receitas de } \\
\text { Transferências } \\
(\mathbf{R T})\end{array}$ & $\begin{array}{c}\text { Despesa com } \\
\text { Pessoal (DP) }\end{array}$ & \%DP/RCL \\
\hline 2008 & $55.641 .581,00$ & $52.644 .670,26$ & $16.883 .907,54$ & 32,73 \\
\hline 2009 & $54.769 .941,74$ & $53.499 .206,20$ & $26.272 .506,31$ & 50,54 \\
\hline 2010 & $63.909 .396,92$ & $61.404 .056,13$ & $32.258 .016,27$ & 53,99 \\
\hline 2011 & $77.752 .871,68$ & $75.523 .128,84$ & $40.318 .281,28$ & $\mathbf{5 5 , 0 9}$ \\
\hline 2012 & $81.645 .145,84$ & $77.925 .787,24$ & $53.132 .593,83$ & $\mathbf{6 8 , 5 9}$ \\
\hline 2013 & $90.399 .533,39$ & $85.546 .467,61$ & $46.400 .746,64$ & 53,61 \\
\hline 2014 & $107.536 .326,95$ & $99.158 .820,97$ & $56.753 .068,96$ & $\mathbf{5 6 , 6 0}$ \\
\hline 2015 & $110.796 .527,90$ & $102.001 .476,20$ & $62.092 .262,53$ & $\mathbf{5 9 , 5 5}$ \\
\hline 2016 & $120.465 .435,16$ & $113.653 .247,22$ & $66.798 .377,65$ & $\mathbf{5 7 , 5 1}$ \\
\hline 2017 & $118.996 .056,92$ & $105.580 .527,94$ & $67.405 .068,41$ & $\mathbf{6 1 , 3 6}$ \\
\hline$\Delta \% 2008 / 2017$ & 113,9 & 100,6 & 299,2 & $\mathbf{8 7 , 5}$ \\
\hline
\end{tabular}

Legenda de cores do destaque

Limite pré-prudencial ou de alerta $(48,60 \%$ a $51,29 \%)$

Limite prudencial $(51,30 \%$ a $53,99 \%)$

Limite máximo ( $54 \%$ ou acima)

Fonte: Elaborada pelos autores (2018), com dados do Portal de Transparência dos Municípios.

Percebe-se, nos últimos anos, que Pacajus vem efetivamente arrecadando menos que o previsto em seu orçamento. As receitas de transferências que representam mais de $90 \%$ da arrecadação, compostas principalmente de recursos da educação, do Fundo de Participação dos Municípios (FPM) e do Imposto de Circulação de Mercadorias e Serviços (ICMS), não estão crescendo o suficiente para sozinhas cobrir todas as despesas do município (CEARÁ, 2018). 
As receitas tributárias, que giram em torno de 5\% de sua arrecadação total, são compostas principalmente pelo ISS e pelo IRRF. O valor arrecadado com o IPTU, apesar de vir crescendo nos últimos anos, ainda é muito baixo 7,79\% das RA, que totalizou R\$ 460.156,86 em 2017 (CEARÁ, 2018).

Este cenário sugere que o município de Pacajus não adotou as medidas necessárias para eliminar o excesso das despesas com pessoal no prazo legal estabelecido, e consequentemente, não está atendendo aos requisitos para responsabilidade na gestão fiscal, tendo em vista a baixa arrecadação dos tributos de sua competência.

Percebe-se, no Gráfico 4, uma elevada participação das RT nos valores arrecadados, o que revela grande dependência deste município de recursos de terceiros e, considerando a variação das RT de 2016 para 2017, observa-se uma tendência de queda desta variável, o que pode agravar ainda mais a situação deste município.

Gráfico 4: Evolução da receita arrecadada, receita de transferência e despesa com pessoal Pacajus, de 2008 a 2017

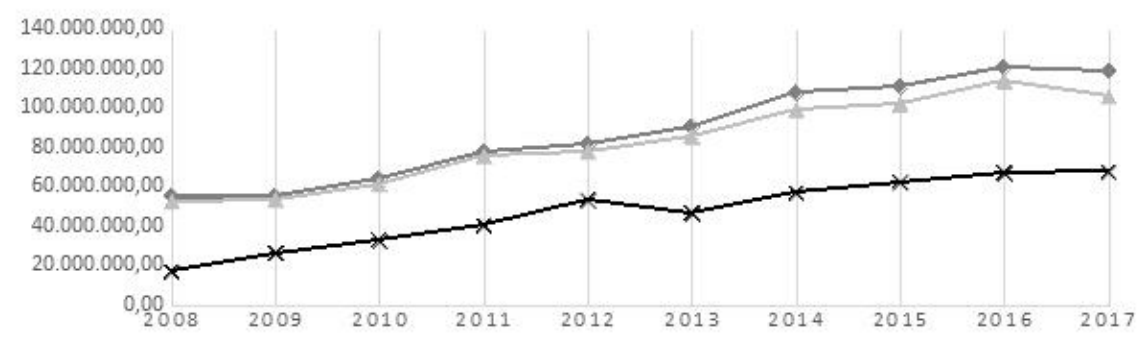

Fonte: Elaborado pelos autores (2018), com dados do Portal de Transparência dos Municípios.

$\mathrm{Na}$ análise combinada dos Gráficos 1 ao 4 verifica-se forte dependência dos municípios em relação aos recursos externos. As receitas de transferências recebidas pelos dois municípios com pior desempenho, Guaiúba e Pacajus, representam, em média, mais de 90\% de suas respectivas arrecadações. Para os municípios com melhor desempenho, a média 
ficou por volta dos $60 \%$. Esses resultados indicam que não se verifica, nos municípios da RMF, um equilíbrio fiscal consistente a longo prazo em razão desta elevada dependência.

Os dados apresentados na Tabela 7 demonstram que, tanto nos municípios com melhor desempenho, na observância dos limites das despesas de pessoal consoante a LRF, como nos municípios com pior desempenho, as despesas com pessoal não variam em função das receitas arrecadadas - isso é, as despesas com pessoal crescem em percentuais maiores que a arrecadação dos municípios.

Tabela 7: $\Delta \%$ das despesas com pessoal X $\Delta \%$ Arrecadação de receitas, de 2008 a 2017

\begin{tabular}{c|c|c} 
Municípios & $\Delta$ Despesas com Pessoal & $\Delta$ Arrecadação de Receitas \\
\hline São Gonçalo do Amarante & $613,8 \%$ & $301,3 \%$ \\
\hline Fortaleza & $135,9 \%$ & $122,7 \%$ \\
\hline Guaiúba & $224,7 \%$ & $135,1 \%$ \\
\hline Pacajus & $299,2 \%$ & $113,9 \%$ \\
\hline
\end{tabular}

Fonte: Elaborada pelos autores (2018), com dados do Portal da Transparência dos Municípios.

\section{CONSIDERAÇÕES FINAIS}

O presente trabalho teve como objetivo geral analisar os gastos com pessoal do Poder Executivo nos municípios da Região Metropolitana de Fortaleza no período de 2008 a 2017. Para isso, foi avaliada a participação das Despesas com Pessoal em relação à Receita Corrente Líquida de cada município da RMF e verificado se os valores dos gastos com pessoal sofreram alterações em função das variações na arrecadação de receitas.

Dos municípios analisados, observou-se, conforme Tabela 2, que, em 2008, início da série histórica, apenas Aquiraz (49,32\%), São Luís do Curu (49,45\%) e Maranguape (51\%) se encontravam no limite de alerta, todos os demais se encontrando com índices menores do que $48 \%$ com gastos com pessoal.

Após quatro anos, em 2012, apenas Fortaleza estava abaixo do limi- 
te de alerta. Os outros 18 municípios ou estavam no limite prudencial, ou acima do limite legal. Por fim, em 2017, oito municípios estavam acima do limite máximo de $54 \%$ permitido pela LRF.

Os resultados confirmam parcialmente o primeiro pressuposto desta pesquisa, que afirma que os municípios da RMF estão realizando despesas com pessoal acima do limite permitido pela LRF.

Os valores apresentados nas tabelas de São Gonçalo do Amarante, Fortaleza, Guaiúba e Pacajus, nas quais a variação das despesas com pessoal é superior à variação das receitas arrecadadas no período estudado, confirmam o terceiro pressuposto que afirma que as despesas com pessoal não variam em função das receitas arrecadadas.

A análise indicou que os municípios mais dependentes de transferências intergovernamentais e com baixa arrecadação própria são os que apresentam maior relação $\mathrm{DP} / \mathrm{RCL}$, possuindo uma forte tendência à geração de déficits fiscais, estando também sujeitos aos efeitos de qualquer alteração no nível de desempenho da economia do país.

Em relação à arrecadação das receitas, verificou-se que em São Gonçalo do Amarante, Fortaleza, Guaiúba e Pacajus ocorreram, em alguns anos, quedas no valor arrecadado em comparação ao ano anterior; em todos os demais verificou-se aumento na arrecadação - portanto, o segundo pressuposto que afirma que a arrecadação vem sendo reduzida no período estudado, acarretando o não cumprimento dos limites, é confirmado parcialmente.

Os processos eleitorais são fatores que podem influenciar o comportamento dos governantes. Embora existam mecanismos legais de controle das finanças para esse período - como o que dispõe que é nulo de pleno direito o ato que resulte aumento da despesa com pessoal nos 180 dias anteriores ao final do mandato do titular do Poder-, em 2012 verificou-se um aumento de quase $30 \%$ das despesas com pessoal em relação ao ano de 2008, último ano do mandato anterior. Isso é, em 2012, 17 municípios 
aumentaram suas despesas com pessoal. Em 2016, também ano de eleição municipal, oito municípios aumentaram suas despesas com esse item.

O quarto pressuposto afirma que as despesas com pessoal aumentam nos anos que ocorrem eleições municipais (2008, 2012 e 2016). Com base nos dados estudados, verificou-se que, em virtude de 2008 ter sido o primeiro ano da série histórica, restou prejudicada a análise. Em 2012, verifica-se um aumento na quantidade de municípios que entraram no limite prudencial, enquanto outros ultrapassaram o limite legal. Em 2016, a situação dos gastos permanece semelhante à verificada em 2015. Portanto, esse pressuposto está parcialmente confirmado.

Atingidos os objetivos propostos para a pesquisa, pode-se concluir que os resultados obtidos evidenciam que a maioria dos gestores púbicos dos municípios da RMF não estão comprometidos com as diretrizes e os limites estabelecidos pela LRF. Por isso, os limites impostos pela LRF são tão necessários, embora não sejam suficientes para garantir a existência de gastos eficientes e eficazes.

A pesquisa evidenciou que o conceito de responsabilidade fiscal precisa ser ampliado para além do mero equilíbrio das contas públicas, visto que apenas tal condição não garante que o setor público esteja alocando e distribuindo recursos de forma eficiente. Dessa forma, o Estado necessita ser eficiente fiscalmente e socialmente. Responsabilidade fiscal e social são objetivos que devem caminhar juntos - são conceitos que se completam e não que se anulam.

No caso dos municípios com grande dependência dos recursos das transferências, é preciso implementar medidas visando diversificar a arrecadação municipal por meio da condução de políticas que incentivem o desenvolvimento do comércio e serviço local, empreendendo e inovando quanto à forma de arrecadar e gerir os recursos do município.

Por fim, este estudo poderia ser ampliado, sobretudo na verificação das medidas adotadas pelos municípios que ultrapassaram o limite legal, 


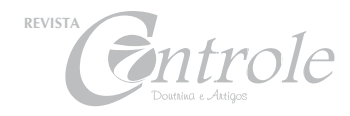

para sua redução dos gastos com pessoal, e na busca por saber qual foi a atuação do Tribunal de Contas na fiscalização e controle desses recursos.

\section{REFERÊNCIAS}

BARBOSA, R. V. N. O comportamento dos gastos com pessoal entre os anos 2001 a 2005 nas capitais brasileiras. In: ENCONTRO DE ADMINISTRAÇÃO PÚBLICA E GOVERNANÇA, 3., 2008, Salvador. Anais [...]. Salvador: Fiesta Bahia Hotel, 2008.

BRASIL. Constituição da República Federativa do Brasil de 1988. Disponível em: https://bit.ly/3n7C0uL. Acesso em: 20 set. 2017.

BRASIL. Lei Complementar $n^{\circ} 101$, de 04 de maio de 2000. Estabelece normas de finanças públicas voltadas para a responsabilidade na gestão fiscal e dá outras providências. Diário Oficial da União, Brasília, DF, p. 1, 5 maio 2000. Disponível em: https://bit.ly/36fHGga. Acesso em: 25 set. 2017.

BRASIL. Secretaria do Tesouro Nacional. Manual de contabilidade aplicada ao setor público: aplicado à União, aos Estados, ao Distrito Federal e aos Municípios: procedimentos contábeis específicos. 2. ed. Brasília: Secretaria do Tesouro Nacional, 2009. (Manual de contabilidade aplicada ao setor público - procedimentos contábeis específicos, v. 3)

CAMPAGNONI, M.; PLATT NETO, O. A. A observância dos limites para despesas com pessoal entre poderes e órgãos da União no período de 2000 a 2013. In: CONGRESSO UFSC DE CONTROLADORIA E FINANÇAS E INICIAÇÃO CIENTÍFICA EM CONTABILIDADE, 5., 2014, Florianópolis. Anais [...]. Florianópolis: Centro de Eventos da UFSC, 2014. 
CEARÁ. IPECE - Instituto de Pesquisa e Estratégia Econômica do Ceará. Fortaleza, 22 jun. 2009. Disponível em: https://bit.ly/2GcRbSG. Acesso em: 25 abr. 2017.

CEARÁ. Tribunal de Contas do Estado do Ceará. Portal da Transparência dos Municípios. Fortaleza, [20-?]. Disponível em: https://bit.ly/33ijh7L. Acesso em: 3 mar. 2018.

CEARÁ. Tribunal de Contas do Estado do Ceará. Relatório de Acompanhamento Gerencial - REAGE. Disponível em: https://bit. ly/36W4Mby. Acesso em: 03 de março. 2018.

COSTA, J. F. Reflexos da lei de responsabilidade fiscal no endividamento dos municípios brasileiros. In: CONGRESSO BRASILEIRO DE CONTABILIDADE, 18, 2008, Gramado. Anais [...]. Gramado: Serra Park Centro de Convenções, 2008.

DOIA, A. R. L. A importância da lei de responsabilidade fiscal para a administração pública. Revista Científica Multidisciplinar Núcleo do Conhecimento, São Paulo, a. 1, v. 7, p. 24-36, 2016.

GIL, A. C. Como elaborar projetos de pesquisa. 6. ed. São Paulo: Atlas, 2017.

GIUBERTI, A. C. Efeitos da lei de responsabilidade fiscal sobre os gastos dos municípios brasileiros. 2005. Dissertação (Mestrado em Economia) - Faculdade de Economia, Administração e Contabilidade, Universidade de São Paulo, São Paulo, 2005.

MOTA, F. G. L. Contabilidade aplicada ao setor público. Brasília: Gestão Pública, 2009. 
OLIVEIRA, W. Curso de responsabilidade fiscal: direito, orçamento e finanças públicas. Belo Horizonte: Fórum, 2015.

SANTOS FILHO, J. E. A lei de responsabilidade fiscal e as finanças públicas: efeitos e consequências sobre os municípios alagoanos (2000 a 2010). 2012. Dissertação (Mestrado em Economia Aplicada) - Faculdade de Economia, Administração e Contabilidade, Universidade Federal de Alagoas, Maceió, 2012.

SOARES, C. S.; FLORES, S. A. M.; CORONEL, D. A. O comportamento da receita pública municipal: um estudo de caso no Município de Santa Maria (RS). Desenvolvimento em Questão, Ijuí, v. 12, n. 25, 2014.

SOUZA, F. J. V.; SILVA, M. C.; CÂMARA, R. P. B. Análises das despesas com pessoal das capitais brasileiras nordestinas. Revista Gestão Organizacional, Recife, v. 11, n. 1, 2018.

VAZQUEZ, D. A. Os efeitos da lei de responsabilidade fiscal sobre as finanças municipais: divisor d'água ou a consolidação de um processo? Temas de Administração Pública, Araraquara, v. 4, n. 7, 2012.

ZONATTO, V. C. S.; HEIN, N. Eficácia da previsão de receitas no orçamento dos municípios gaúchos: uma investigação empírica dos exercícios de 2005 a 2009 utilizando a análise de clusters. Revista Estudos do CEPE, Santa Cruz do Sul, n. 37, p. 102-131, 2013. 